\title{
Study of Ultrastructural Changes on the Cochleae Caused by Various Intonations Used in Classical Music
}

Article in Asian Journal of Cell Biology · February 2008

DOI: $10.3923 /$ ajcb.2008.72.79

CITATIONS

0

9 authors, including:

\section{Erdoğan Bulut}

Trakya University

19 PUBLICATIONS 25 CITATIONS

SEE PROFILE

\section{Cevat Aktas}

Namik Kemal University Faculty of Medicine 57 PUBLICATIONS 564 CITATIONS

SEE PROFILE
READS

20

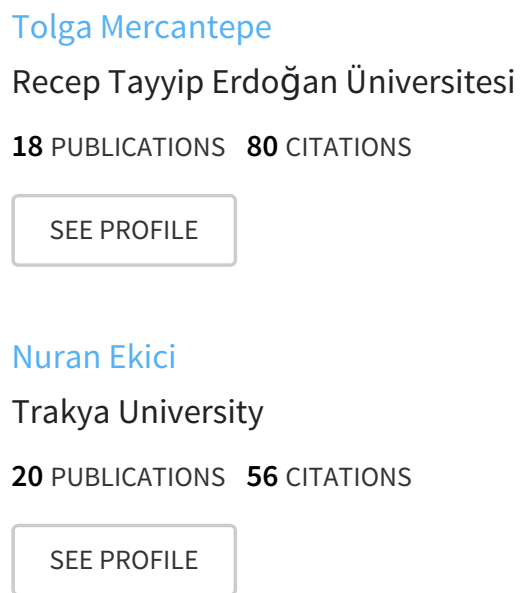

Some of the authors of this publication are also working on these related projects: 


\title{
Study of Ultrastructural Changes on the Cochleae Caused by Various Intonations Used in Classical Music
}

\author{
${ }^{1}$ Leyla Mamedova, ${ }^{2}$ Mehmet Kanter, ${ }^{3}$ Süleyman Sırn Güner, ${ }^{4}$ Erdoğan Bulut, \\ ${ }^{2}$ Tolga Mercantepe, ${ }^{1}$ Işın Metin, ${ }^{5}$ Gülara Hüseyinova, ${ }^{2}$ Cevat Aktaş and ${ }^{6}$ Nuran Ekici \\ ${ }^{1}$ Department of Music, Faculty of Music and Performing Arts, \\ Bilkent University, Bilkent-Ankara, Türkiye \\ ${ }^{2}$ Department of Histology and Embryology, Faculty of Medicine, Edime, Türkiye \\ ${ }^{3}$ Department of Music, Faculty of Music and Performing Arts, \\ Trakya University, Edirne, Türkiye \\ ${ }^{4}$ Department of Physiology, Faculty of Medicine, Trakya University, Edirne, Türkiye \\ ${ }^{5}$ Department of Pathology, Faculty of Medicine, Edirne, Türkiye \\ ${ }^{6}$ Department of Science Education, Faculty of Education, \\ Trakya University, Edirne, Türkiye
}

\begin{abstract}
The aim of this study is to investigate the differences on ultrastructure of the cochleae caused by different classic musical opuses with different intonations. Guinea pigs were grouped into 3 , one of which was the control and the other two were the experimental groups. While the first group, which was the control, was not exposed to any music, the second group was exposed to classic musical opuses with extensive intervals ( 40 decibel) and third group was exposed to classical music opuses with strained intonations ( 60 decibel) for $6 \mathrm{~h}$ a day with $15 \mathrm{~min}$-intervals for totally 10 days. Cochleae tissue samples were taken from the guinea pigs at the end of the tenth day. They were examined at the electron microscopic level. In addition to compansatris processes on the cochleae, thickening on the stereocilias of hair cells and basal membranes and proliferation on the synaptic terminalles of afferent nerves caused by extensive intonations were observed. Extremely obvious degenerative differences such as damage in neuroepitelial cells, nerves and synaptic terminalles as well as compansatris processes caused by strained intonations were determined. As a result of all these observations it was concluded that continuously listening to the strained intonations used in musical opuses has a very harmful effect on the auditory system.
\end{abstract}

Key words: Cochleae, music, intonation, ultrastructure

\section{INTRODUCTION}

Classical music opuses are formed of various intonations. These intonations are used in order to explain the musical sentences, styles and characters. A musical intonation is formed by using two or three tones. These tones form an interval. There are specific rules to form these intervals used in classical music opuses. Close ones are the sekunda and kvarta intervals and they denote the strained intonations. These intervals usually show feelings and thoughts such as war, command, complaint, desperation, courage and freedom in music (Vahromeev, 2000). They are mostly used in national marches and governmental ceremonies. More extensive intervals, on the other hand, are the kvinta, seksta, septima, oktava intervals and are mostly used in lyrics and romantic opuses (Buluchevski and Fomin, 2002). These intervals are transmitted in music with high and low voices in different balances.

Corresponding Author: Nuran Ekici, Department of Science Education, Faculty of Education,

Trakya University, Aysekadin Yerleskesi 22030, Edirne, Türkiye Tel: 90-284-2120808 (1308) Fax: 90-284-2146279 
The effect of musical intonations on the organism is extremely important. Some authorities have indicated that in complex rhythms balances in high voices ( $60 \mathrm{~dB}$ and more) may have harmful effects on the organism (Slepova, 2000; Hetu and Fortin, 1995). In the literature there are very few studies about the effects of musical voices on the auditory system. These studies were mostly done using light microscopy. There is no study on this topic done at the ultrastructural level.

The aim of this study is to examine the effect of different musical intonations used in classical music opuses on the auditory system of the organism at the macromolecular level and to compare the functional changes.

\section{MATERIALS AND METHODS}

This study is done with the cooperation of department of Histology and Embryology in Trakya University (Edirne) and department of Music and Arts in Bilkent University (Ankara) in 2006. In this study, 15 young-adult guinea pigs that had auropalbepral reflexes were used. The guinea pigs were randomly grouped into three. The five guinea pigs in the first group were control group. Five guinea pigs in the second group were exposed to classical music opuses with extensive intervals (40 decibel) for $6 \mathrm{~h}$ a day with 15 min-intervals for totally 10 days. These opuses were the Mozart's Re-minor piano, Schubert's Ave Maria, P. Tchaikovsky's Seasons and Chopin's Waltzes. Five guinea pigs in the third group were exposed to classical music opuses with strained intervals ( 60 decibel) for $6 \mathrm{~h} \mathrm{a}$ day with 15 min-intervals for totally 10 days. These opuses were national marches, military songs, I.S. Bach-Choral prelude, Wagner, scene of Vernizberg, etc. Classical music opuses were received in standard silent rooms. Sound level in the standard silent rooms were continuously measured with Casella 2000 brand CEL 440 model Sound Level Meter (Denmark) and at the end of the experiment, average of maximum and minimum sound levels were obtained. At the end of the tenth day, the guinea pigs were killed under high dose of anesthesia (thiopental-Na) and their heads were removed by decapitation. Cochleae from their head were exposed by temporal bone dissection. During the decalcification process, biopsy material was treated with EDTA for a week. For the electron microscopical examination, a $1.5 \mathrm{~h}$ pre-fixation was applied to the tissues in a phosphate tampon with $\mathrm{pH} 7.3$, which involved $2.5 \%$ of glutaraldehyde. After that, an hour of post fixation was applied in the $1 \% \mathrm{OsO}_{4}$ solution of the same tampon. The materials were dehydrated by passing through high levels of alcohol, were made transparent in propylene oxide and were blocked in araldite. Semi-thin sections were taken (RMC-MTX Ultramicrotom-USA), were colored in azur blue and thin sections of 40-60 nm were taken, which were colored with Reynolds's leaden citrate colorings in order to increase uranil acetate and contrast. These sections were examined under JEOL-Jem 1010 electron microscope and the results were demonstrated.

\section{RESULTS}

In the electron microscopical examination of the control group, it was seen that cochleae was formed of neuroepitelial cells and cellula pillosa interna and cellula pillosa externa, which are the receptor elements of the spiral organ. On the apical of cellula pillosa interna and cellula pillosa externa, stereocilias were determined located parallel to cuticula. Basal cells (deiteis cell, genzen cell, klaudus cell) were observed on the basal regions of cellula pillosa interna and cellula pillosa externa. These cells which were different from the receptor hair cells were close to the basal membrane. In addition, a big amount of afferent nerve terminals with light neuroplasm and efferent nerve terminals with dark neuroplasm were determined on the basal region. These nerve terminals had parts formed of cellula interna and cellula externa. On the scale tympani section, endothelial cells and basilar fibrils were observed (Fig. 1). In the cytoplasm of the basal cells, a great amount of dense granules and afferent and efferent nerve terminals were determined (Fig. 2). 


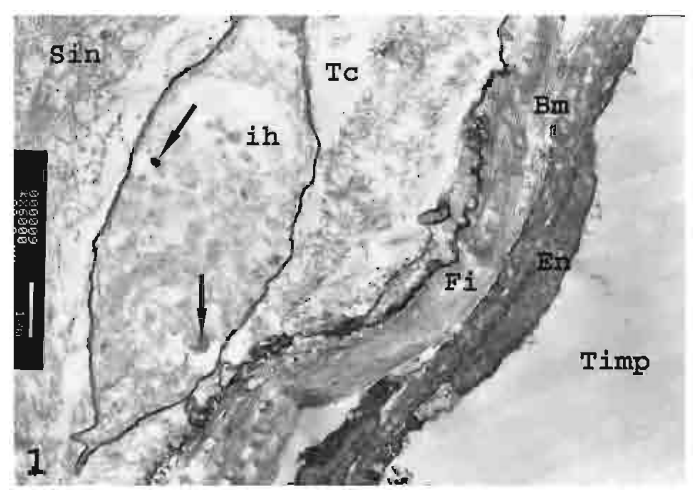

Fig. 1: Group 1 (Control): Cochlear basilar membrane; zona arcuata; radial shaped small (Fi) collagen fibrils inside $(\mathrm{Bm})$ basilar membrane are observed. (En) Endothelial cells with flat nuclei are observed along the side of (Timp) scale timpani. On the side of (Tc) Corti Tunnel, the extension of cellula pillosa interna and (Sin) synaptic contacts are observed. $(\downarrow)$ Neuroflaments are observed in the cytoplasm of the extension of cellula pillosa interna ( $\mathrm{x} 6000)$

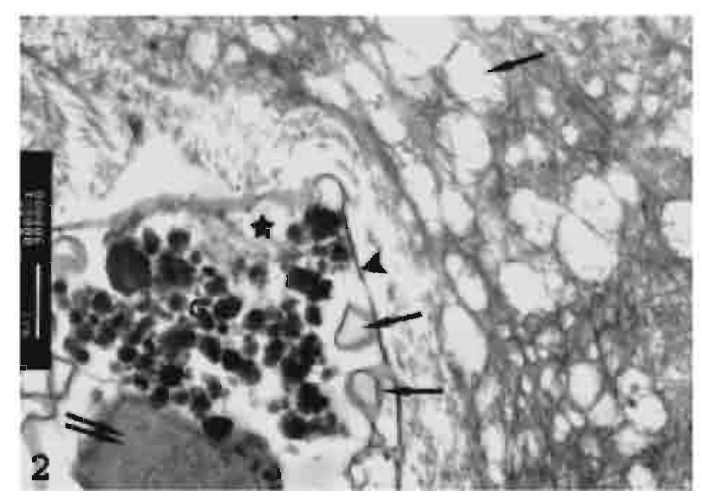

Fig. 2: Group 1 (Control): Supporting cells of the spiral organ in the cochlea $\left(^{*}\right)$ are observed. Particularly in the cytoplasm, beside a big amount of $(G)$ dense granules, $(\downarrow)$ afferent synaptic contacts with light matrix and efferent nerve terminal with dark and dense matrix $(\downarrow \downarrow)$ are seen. (•) Cell membrane (x8000)

It was determined that the parallelism disappeared with the thickening in the stereocilias of the hair cells in cochleae and the basal membranes caused by extensive intonations of the classical music opuses (Fig. 3).

Around the hair cells and basal cells, a big amount of developed nerve extensions that were attached together and had light cytoplasm (neuroplasm) and prolifications of synaptic terminals were observed (Fig. 4, 5).

It was determined that with the effect of strained intonations used in classical music opuses the stereocilias on the apical of the hair cells of the cochleae were thickened and their hypertrophy and parallelism were damaged and some of them were broken (Fig. 6). In addition very obvious degenerative differences were determined such as disturbance of some of the hair cells and collapsing of the nerves and synaptic terminals (Fig. 7). 


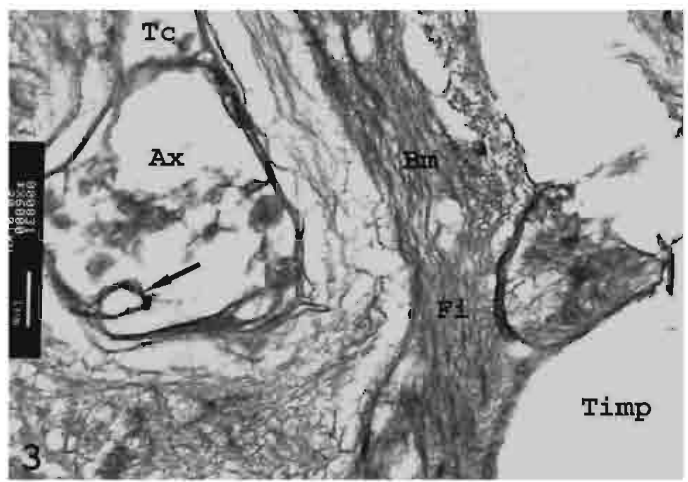

Fig. 3: Group II: Thickenings of the fibrils on the cochlear (Bm) basal membrane (Fi) caused by extensive intonations are observed. (Ax) The fiber with less myelin on the bipolar spiral ganglion is seen. $(\downarrow)$ Concentric folding of the plasma membranes is observed (x6000)

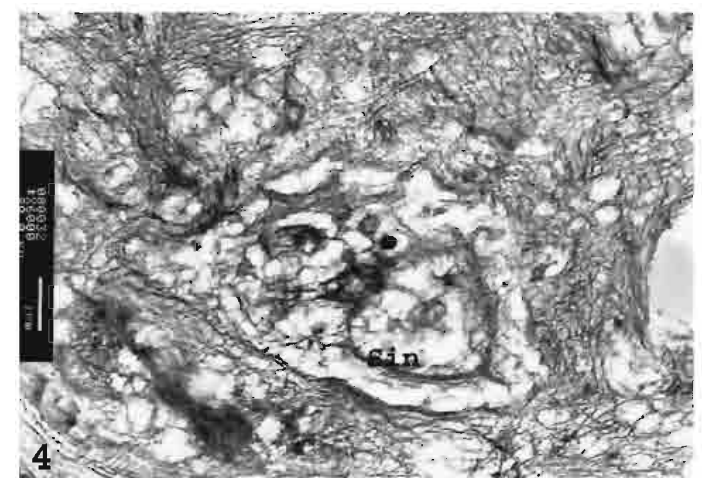

Fig. 4: Group II: Profiration of the osmophilic elements on the (Sin) synaptic nerve terminals on the cochlea caused by extensive intonations is seen (x6000)

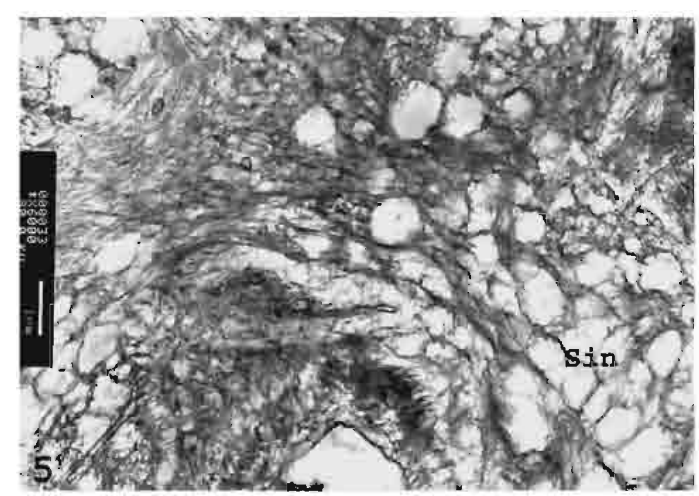

Fig. 5: Group II: Increase in the number of afferent synaptic terminals with light cytoplasm (Sin) caused by extensive intonations is seen (x6000) 
Asian J. Cell Biol., 3 (2): 72-79, 2008

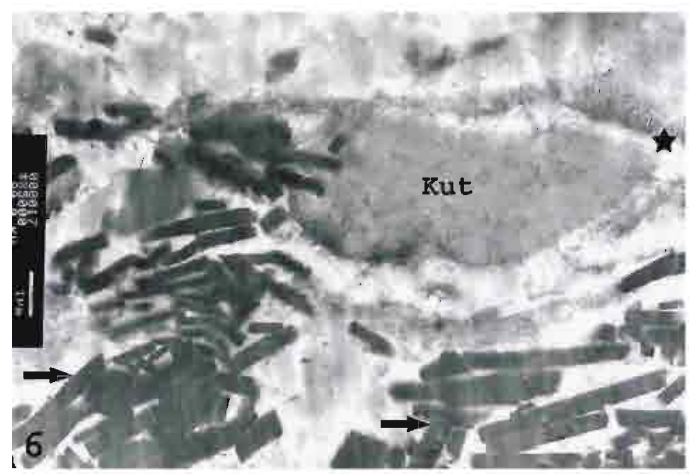

Fig. 6: Group III. (Kut) Kutikula caused by extensive intonations is seen on the apical of hair cell on the cochlea $(*) .(\downarrow)$ Thickening and hypertrophy in the Stereocilias, damage in some of them and damage in the parallelism of some of them are observed ( $x 5000)$

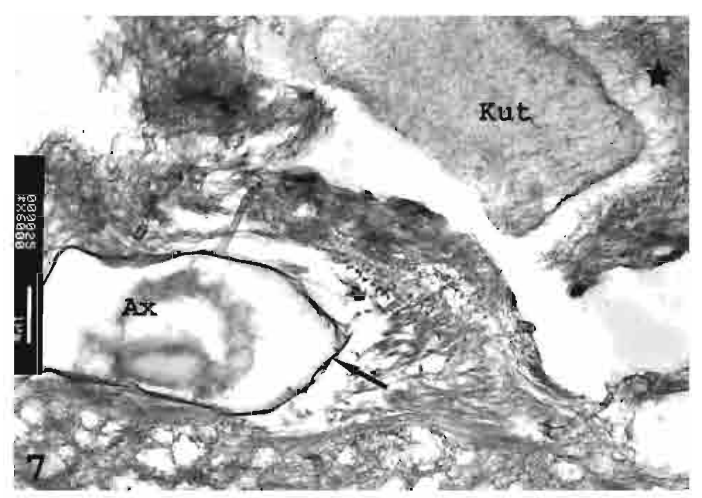

Fig. 7: Group III: Disturbance of the hair cell on the cochlea (*) and degeneration of (Ax) amyelin nerve caused by extensive intonations are observed. (Kut) Kutikula, ( $\downarrow$ ) Aksolemma (x6000)

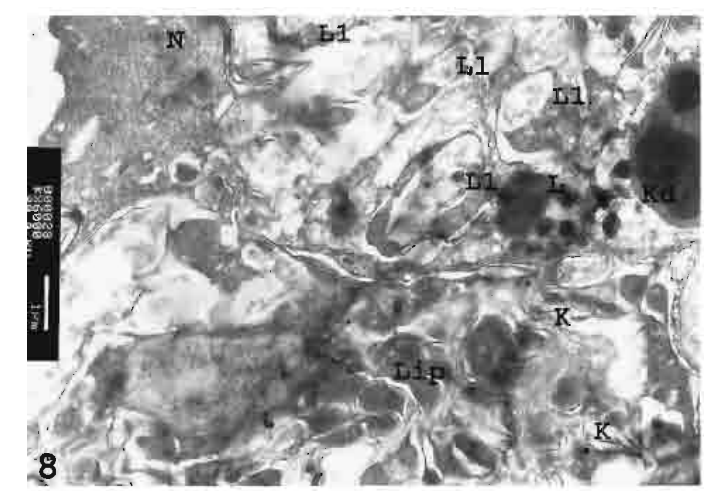

Fig. 8: Group III: Macrophage caused by extensive intonations is seen on the cochlear endolympha In the cytoplasm, in addition to a big amount of primer (L) lysosomes and (L1) autophago lysosomes, lysed $(\mathrm{K})$ collagen fibrils, (Lip) lipids and blood vessels are seen. Besides, an active macrophage whose nucleus has a great number of promontory is observed ( $\mathrm{x} 6000)$ 


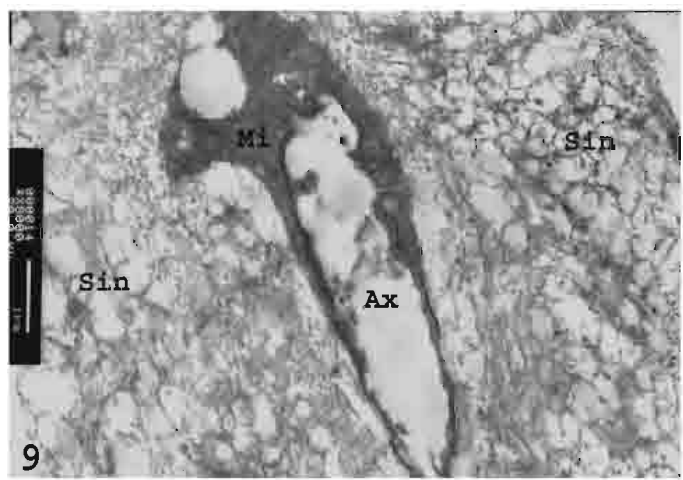

Fig. 9: Group III: A degenerated myelin nerve fiber caused by extensive intonations is observed on the cochlea (Ax); around it, an increase is observed in the proliferation of the osmophilic elements on the afferent synaptic terminals with light cytoplasm (Sin). (Mi) Myelin (x8000)

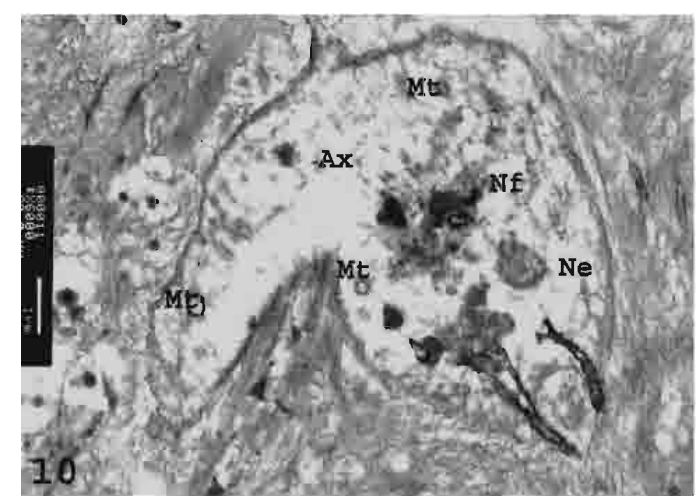

Fig. 10: Group III: A cross section of the efferent axon of the bipolar neuron (Ax) of the spiral ganglion on the cochlea caused by extensive intonations is seen. (Mt) Microtubules, (Nf) neuroflaments and $(\mathrm{Db})$ dense bodies are seen in the $(\mathrm{Ne})$ neuroplasm $(\mathrm{x} 6000)$

Macrophagial reactions were observed on the endolymph with the effect of strained intonations (Fig. 8). In addition a great amount of degenerated preterminal axons with afferent myelin with light neuroplasm and efferent nerves with dense neuroplasm were observed. With contrast to degeneration, an increase was determined in the proliferation of osmiophilic materials on the synaptic terminals (Fig. 9, 10).

\section{DISCUSSION}

Musical intonation is the basis of the music character and melody of any kind. Questioning, screaming, breath taking, excitement, crying, happiness and other feelings are all expressed with intonations in music. Classical music opuses are formed of various intonations (Vahromeev, 2000). Strained intonations, complex rhythms, high tones ( $60 \mathrm{~dB}$ and more) are harmful for the organism (Hetu and Fortin, 1995). Sound waves cause reflector reactions on the organism. Musical impulses firstly stimulate the afferent nerve receptors and with the afferent nerve, the sensorial knowledge is transmitted to the central nervous system (centre of integration). The manipulated sensorial knowledge 
forms a motor reaction on the efferent nerves and the effectors (Ortiz-Hidalgo and Weller, 1992). In our studies, strained and extensive intonations formed various reactions on the neuromuscular connections with high voices (60dB and more) in different musical balances (Mamedova et al., 2007, 2008). In an experimental study in which an experiment is done on a few guinea pigs, Seratonin hormon was found to be high in the blood-hormonal levels of the guinea pigs (Rauscher et al., 1993). Classical music opuses are widely used in treatment with music too. Some authors have evaluated classical music opuses as positive and negative (Bailey, 2001). In this study, it was found that there was a thickening in the stereocilias of the hair cells and basal membrane of the cochleae caused by extensive intonations used in classical music. In addition proliferation of the synaptic terminals of the afferent nerves (acsons and dendrits) was observed. These formations were the indicator of the formation of compansatris processes of the sound waves on the cochleae. With the effect of strained intonations, in addition to the stereocilias of hair cells in the cochleae and compansatris hypertrophy of the basal membrane, degenerative changes (the damage in the order and parallelism of the stereocilias where the cells were degenerated) also occurred.

Acute degenerative changes were determined on the synaptic terminals on the afferent, efferent miyelin and amiyelin nerves of the bipolar neurons. Sound waves are transmitted to the Corti organ settled on the basal membrane. Receptors of the Corti organ are consisted of cellula pillosa interna and cellula pillosa externa. There are cuticulas and stereocilias on the apical of these cells at the electron microscopic level. These structures are highly sensitive to sound waves. The supporting cells close to the basal areas of the hair cells and the afferent and efferent nerves of the bipolar neurons of the spinal ganglion of the cochleae are observed. Functionally, various types of enzymes, monophosphoesterase, proteins, nucleic acids, asetilkolinesteraz, glycogen and other enzymes are synthesized on the hair cells. These play an important role on the auditory system. Sound waves pass through perilenpha in scala timpani and form a vibration on the basilar membrane through the circular hole. In relation to this process, specific biochemical processes and bioenergitic reactions are formed in the hair cells (Raphael and Altschuler, 2003).

These processes are structurally formed in the macromolecules (ultrastructures) of the cells. Structural dejenerations cause functional failures. For this reason, as a result of the stimulation of the cochleae with the musical sounds, monophosphooesterase, proteins, nucleic acid, asetilcholine esterase, glycogen and other fermentative activities increase because of extensive intonations and these activities decrease because of strained intonations.

\section{CONCLUSION}

With the effect of the extensive intonations used in the classical music opuses, adaptivecompansatris processes (thickening in the hair cell stereocilias and basal membrane, proliferation of the nerves and synapses) were formed on the macromolecules of the cochleae and fermentative activity was increased. With the effect of the strained intonations, in addition to adaptive processes (hypertrophy of the hair cells and thickening of the basal membrane), acute degenerative processes (disturbance of the hair cells, damage in the order and parallelism of stereocilias and collapsing of the nerves) were observed. Related to these ultrastructural changes, there was a decrease in fermentative activity and sound transmission.

In our opinion, auditory system can be damaged when the extensive intonations used in classical music opuses are continuously listened to.

\section{REFERENCES}

Bailey, T., 2001. Music as medicine: The history of music therapy since antiquity. A review. Notes, 57: 603-604. 
Buluchevski, Y. and V. Fomin, 2002. Theory of Music (Book for Students). 1st Edn. Moscow Music, Moscow, pp: 21-32.

Hetu, R. and M. Fortin, 1995. Potential risk of hearing damage associated with exposure to highly amplified music. J. Am. Acad. Audiol., 6: 378-386.

Mamedova, L., I. Metin, N. Ekici, M. Hüseyinov, G. Hüseyinova and M. Kanter, 2007. An ultrastructural study on the effects of different musical timbres on the skeletal muscle cells. Asian J. Cell Biol., 2: 43-49.

Mamedova, L., I. Metin, N. Ekici, M. Huseyinov, G. Huseyinova and S.S. Guner, 2008. Effects of Various Intervals applied in classical music on the ultrastructure of reflector nerve and muscle terminals (A musical, medical, biological and experimental study). Asian J. Cell Biol., 3: 41-46.

Ortiz-Hidalgo, C. and R.O. Weller, 1992. Peripheral Nervous System. Histology for Pathologist. Ch. 7, Raven Press, New York, pp: 169-193.

Raphael, Y. and R.A. Altschuler, 2003. Structure and innervation of the cochlea. Brain Res. Bull., 60: 397-422.

Rauscher, F., G. Shaw and K. Ky, 1993. Mozart and spatial reasoning. Nature, 365: 611-611.

Slepova, A., 2000. Music for Therapy. 1st Edn. Moscow Music, Mosco, pp: 53-65.

Vahromeev, V., 2000. Elementary Theory (Book for Students). 1st Edn. Moscow Music, Moscow, pp: $43-51$. 